\title{
ASO Author Reflections: The Peritoneum is an Active Immunological Compartment
}

\author{
Ebbe Billmann Thorgersen, $\mathrm{MD}, \mathrm{PhD}^{1,2}$, and Kjersti Flatmark, $\mathrm{MD}, \mathrm{PhD}^{1,3,4}$ \\ ${ }^{1}$ Department of Gastroenterological Surgery, Oslo University Hospital, The Radium Hospital, Oslo, Norway; ${ }^{2}$ Department \\ of Immunology, Oslo University Hospital Rikshospitalet, Oslo, Norway; ${ }^{3}$ Faculty of Medicine, University of Oslo, Oslo, \\ Norway; ${ }^{4}$ Department of Tumor Biology, Oslo University Hospital, The Radium Hospital, Oslo, Norway
}

\section{PAST}

Cytoreductive surgery (CRS) and hyperthermic intraperitoneal chemotherapy (HIPEC) is established as standard-of-care treatment for selected patients with resectable peritoneal surface malignancies, such as peritoneal metastasis from colorectal cancer (PM-CRC). ${ }^{1}$ Although CRS-HIPEC may improve overall survival, the majority of patients experience disease relapse and new treatment options are needed. ${ }^{2}$ Anticancer therapy exploiting immune mechanisms, including inflammation, could potentially be an interesting strategy in compartmentalized treatment in the peritoneal cavity ${ }^{3}$ however, little is known about local and systemic immune response after major abdominal surgery.

\section{PRESENT}

In the recent work 'Increased Local Inflammatory Response to MOC31PE Immunotoxin After Cytoreductive Surgery and Hyperthermic Intraperitoneal Chemotherapy', a highly compartmentalized, broad, and substantial intraperitoneal inflammatory cytokine response was identified after CRS-HIPEC compared with a modest systemic inflammatory response. ${ }^{4}$ Several cytokines exhibited distinct time-dependent release patterns, some with very high intraperitoneal peak levels. The response was further

(C) The Author(s) 2021

First Received: 15 March 2021

Accepted: 17 March 2021;

Published Online: 3 May 2021

E. B. Thorgersen, $\mathrm{MD}, \mathrm{PhD}$

e-mail: ebbtho@rr-research.no enhanced in patients who received treatment with MOC31PE immunotoxin targeting epithelial cell adhesion molecule. Of particular interest, several of these cytokines, including the classical proinflammatory cytokine interleukin-6, and the T-cell stimulator interferon (IFN)- $\gamma$ and its companion IFN-induced protein-10, are involved in processes related to immune activation with a potential anticancer effect, such as immunogenic cell death.

\section{FUTURE}

Interpretation of these findings is challenging because of the dualistic nature of inflammation as both a promoter and inhibitor of cancer initiation and progression ${ }^{5,6}$ It is further complicated by temporal issues, where the chronic lowgrade inflammation in a tumor microenvironment will differ from acute inflammation caused by surgical intervention. The peritoneum seems to be a very active immunological 'organ', and improved knowledge of peritoneal biology, in particular of humoral and cellular immune mechanisms, would likely improve our understanding of peritoneal cancer dissemination and its treatment. Analysis of immune cells in tissues and peritoneal fluid before and after CRS-HIPEC is a logical next experimental step. The knowledge could be essential to precisely tailor-make new immunomodulating treatment regimens as a supplement to CRS-HIPEC for PM-CRC to improve long-term oncological outcomes.

FUNDING Open access funding provided by University of Oslo (incl Oslo University Hospital).

DISCLOSURES Ebbe Billmann Thorgersen and Kjersti Flatmark declare no conflicts of interest. 
OPEN ACCESS This article is licensed under a Creative Commons Attribution 4.0 International License, which permits use, sharing, adaptation, distribution and reproduction in any medium or format, as long as you give appropriate credit to the original author(s) and the source, provide a link to the Creative Commons licence, and indicate if changes were made. The images or other third party material in this article are included in the article's Creative Commons licence, unless indicated otherwise in a credit line to the material. If material is not included in the article's Creative Commons licence and your intended use is not permitted by statutory regulation or exceeds the permitted use, you will need to obtain permission directly from the copyright holder. To view a copy of this licence, visit http://creativecommons. org/licenses/by/4.0/.

\section{REFERENCES}

1. Elias D, Gilly F, Boutitie F, et al. Peritoneal colorectal carcinomatosis treated with surgery and perioperative intraperitoneal chemotherapy: retrospective analysis of 523 patients from a multicentric French study. J Clin Oncol. 2010;28(1):63-8.

2. Froysnes IS, Larsen SG, Spasojevic M, Dueland S, Flatmark K. Complete cytoreductive surgery and hyperthermic intraperitoneal chemotherapy for colorectal peritoneal metastasis in Norway: prognostic factors and oncologic outcome in a national patient cohort. J Surg Oncol. 2016;114(2):222-7.

3. Froysnes IS, Andersson Y, Larsen SG, et al. Novel treatment with intraperitoneal MOC31PE immunotoxin in colorectal peritoneal metastasis: results from the ImmunoPeCa phase 1 trial. Ann Surg Oncol. 2017;24(7):1916-22.

4. Thorgersen EB, Asvall J, Froysnes IS, Schjalm C, Larsen SG, Dueland $\mathrm{S}$, et al. Increased local inflammatory response to MOC31PE immunotoxin after cytoreductive surgery and hyperthermic intraperitoneal chemotherapy. Ann Surg Oncol. 2021. https://doi.org/10.1245/s10434-021-10022-0.

5. Diakos CI, Charles KA, McMillan DC, Clarke SJ. Cancer-related inflammation and treatment effectiveness. Lancet Oncol. 2014;15(11):e493-503.

6. Monteleone G, Pallone F, Stolfi C. The dual role of inflammation in colon carcinogenesis. Int J Mol Sci. 2012;13(9):11071-84.

Publisher's Note Springer Nature remains neutral with regard to jurisdictional claims in published maps and institutional affiliations. 